\title{
Chapter 3 \\ Paraguayan Indigenous Peoples and the Challenge of Citizenship
}

\author{
Dominique Demelenne
}

\begin{abstract}
We consider that citizenship education policies should be a product of a socially informed process where we must question whether it is possible to build a dialogue between cultures that do not share the same world-view. We must therefore reflect critically on what has resulted from the meeting of cultures in Latin America, and understand the fundamental knowledge of Indigenous Peoples which relates to their specific conceptualization of citizen education. This leads us to rethink the meaning of education, participation and the relationships between humans and the environment.

To better understand the issues and challenges of citizenship education in this context, this chapter will focus on the case of the Indigenous Peoples of Paraguay. To do so, we will outline Indigenous epistemologies and worldviews, and identify the challenges of a truly intercultural dialogue between different epistemologies. This will allow us to envision culturally relevant citizenship education for Indigenous Peoples.
\end{abstract}

Keywords Indigenous education · Interculturality $\cdot$ Citizenship education

\section{Introduction}

In 1993, Paraguay took an important step forward by introducing an educational reform defined as bilingual and intercultural. However, it is important to note that this reform neglected the issues of Indigenous education. It was not until the adoption of the General Law of Education in 1998 and the creation of the Department of Indigenous School Education that the identity of Indigenous Peoples was recognized in educational policies.

However, despite these efforts, the gap between Indigenous and non-Indigenous populations persists. To reduces these inequalities, we believe it is necessary to build programs and policies based on effective participation and dialogue. To this

D. Demelenne $(\bowtie)$

Catholic University of Asuncion, Asunción, Paraguay

e-mail: dominique_demelenne@hotmail.com 
end, we need to first question the feasibility of building an in-depth dialogue between cultures with very different world-views. This chapter therefore aims to explore the potential for expansion of the scope of global citizenship to include the active participation of Indigenous Peoples. Furthermore, the very concept of global citizenship education (GCE) leads us to rethink Indigenous education and Indigenous citizenship.

As in many academic studies in Latin America, the question of Indigenous knowledge poses numerous epistemological and methodological challenges, (see for example the minutes of the colloquium "multiple knowledge and social sciences", Gómez et al. 2018). Our approach aims to bring a new perspective and to create a dialogue between different Indigenous leaders consulted in recent years and theoretical works of thinkers such as Raúl Fornet-Betancourt and Arturo Escobar.

\section{Indigenous Education in Paraguay}

Working with Indigenous communities in Paraguay first took place at the end of the twentieth century, following the enactment of the General Education Act No. 1264/98, with specific projects involving only a few schools and supported by social and religious organizations. At the time, Paraguay did not have a definite plan, leaving private organizations to develop the first programs and materials for Indigenous schools. For instance, the Association for Cooperation of the Mennonite Church has long supported a large group of Indigenous schools where the Mennonite cooperatives have influence in the Central Chaco region. The Catholic association CONAPI (Coordinación Nacional de Pastoral Indígena) worked to introduce Indigenous education within educational reform, prepared the Indigenous education bill, and supported its implementation along with a steering committee of Indigenous representatives of the 19 Indigenous Peoples of Paraguay. In 2008, the creation of the Department of Indigenous School Education (DGEEI) made possible the approval of projects based on the rationale of focus-group experiences to establish a framework of action. This framework sought to regulate the law and to specify its scope. This is how the Indigenous School Education was slowly defined:

A learning process guided and transmitted by teachers, and supported by the Indigenous community, where two teaching systems are articulated. These are the Indigenous and the National systems, so that the participants strengthen their culture, acquire general knowledge, and that of other cultures as well (DGEEI 2013, translated from Spanish).

Accordingly, the Indigenous School Education intercultural proposal was designed to act as an 'exchange space' between informal education and formal schooling. Built initially on the foundations of Paraguay's national education program, it gradually sought its own meaning. For example, it defined the fundamental elements of Indigenous School Education as follows (DGEEI 2013): 
- Being Indigenous: each community defines what it means to be Maskoy, Mbyá, Nivacle, ... and what is expected of its members

- Learning to coexist and to live together is to discover the deep meaning of a culture, to understand its spirituality. It is therefore important to start from a worldview in order to discover the meaning of the world according to each culture.

- Sharing: a person in receipt of knowledge should not keep it for themselves, but use it to serve the community. Knowledge is a social asset for the community.

- By doing: knowledge is solidified. Through community education, children learn what skills are needed in their environment (fishing, dancing, singing, etc.). Culturally significant activities should be articulated with academic content.

- Knowing: They learn science, communication, mathematics, and what is necessary to actively participate in a global society.

To build this educational proposal, it was necessary to recognize the importance of Indigenous languages (19 Indigenous languages are spoken in Paraguay), each Indigenous Peoples' cultural identity, wisdom and knowledge, the natural biodiversity of each local territory, and Indigenous spirituality which is the root of the Indigenous way of life and social practices.

In this respect, a single action framework could not be used and it was necessary to think of how to formulate a specific proposal for each of the 19 communities. As this could not be done from an office or by a group of experts, Indigenous teachers were trained in intercultural research methodology that had been used previously in Ecuador. Teachers therefore became researchers of their own reality and acted on rescuing Indigenous knowledge, infusing it in the curriculum and creating culturally relevant teaching material (Demelenne 2010).

There's a lot of talk about participation. That is what we always expect. We believe that the Indigenous Peoples, and especially the Indigenous teachers, should take part in the preparation of the curriculum. The most important thing is to understand the conceptual elements that are the basis of Indigenous cultures. Territory, health, environment, and food security are fundamental components to be considered in order to develop the proposal. The law says that all the members of the community must participate in the preparation of the curriculum (Teacher of the Mbyá Guarani community, Itapua).

It was an ambitious proposal considering that many Indigenous teachers did not have professional training. Their role was nevertheless essential since they had the advantage of local knowledge and proximity with the community elders. However, this first attempt at formulating proposals for each culture was still far from an effective response to the needs of the different communities. 


\section{A Globalized World with Significant Gaps}

To understand the context and the current needs of Indigenous Peoples in Paraguay, we can use the data provided by Tauli-Corpuz (2015) in her report to the United Nations. ${ }^{1}$ The report points out that in the Indigenous population, people over the age of 15 years have had an average of 3 years of schooling compared to 8 years for the non-Indigenous population. It is clear that in terms of the right to education, even though the number of students enrolled in basic education has increased, there are still significant differences in the gross rate of schooling among Indigenous and non-Indigenous population.

As for the socioeconomic situation, although extreme poverty has declined in Paraguay (DGEEC 2014), the available data shows that $66.2 \%$ of the population is in a situation of poverty and $34.4 \%$ in extreme poverty. The incidence of poverty is twice the national average, and extreme poverty triple the national average among Indigenous Peoples. For those under 5 years of age, the extreme poverty rate is $63 \%$ (compared the national average of 26\%) and chronic malnutrition $41.7 \%$ (compared to $17.5 \%$ ) (Ministry of Agriculture and Livestock, INDI, and FAO 2014). Indigenous representatives constantly demand measures to address the lack of food security and access to drinking water (especially in the Chaco region), because there are serious and recurrent problems associated with both. The illiteracy rate of Indigenous Peoples aged 15 or older is $33.3 \%$, with a maximum of $40.8 \%$ for women. Access to electricity is available to only $59.4 \%$.

Facing these realities, the report recommends among other things:

The formulation, adoption and implementation of a national public policy on Indigenous education that gives effect to Indigenous Peoples' right to education, which includes their right to establish their own educational systems in their own languages. The policy should also provide for special measures to ensure access to the general education system, especially in secondary and tertiary levels; the implementation of a review of the curricula used in the general education system - in order to ensure that these promote interculturalism and contribute to a better understanding of, and due respect for, Indigenous Peoples and their history, heritage, culture, and rights (Tauli-Corpuz 2015, p.21).

The report ends by affirming the urgency of an in-depth dialogue with Indigenous organizations to identify causes and design effective public policies to resolve the problems identified.

\footnotetext{
${ }^{1}$ Special Rapporteur on the rights of Indigenous peoples.
} 


\title{
Bases of an Intercultural Dialogue
}

It is not the first time that a report highlights the need for dialogue with Indigenous organizations. But what is meant by an in-depth dialogue? In a study previously conducted in Indigenous communities in Paraguay, a Mbyá community leader describes his experience:

\begin{abstract}
We would have been the first, but it has been two years and we are still not the first (...) because the white men went to the communities collecting the data, but they never come back. And the communities ask what happened with our data, who took it and why they do not come to tell us what the plan was (...). We have always taken part in public policies, we contributed with our votes in the presidential and municipal elections, but there was never a true participatory space for Indigenous Peoples. We are many, we are all poor. Why? Because the State seems to isolate us, we seem to be in another country and not in Paraguay. We always ask why. Why have we lived like this if so many projects include Paraguay and why are they not given to Indigenous Peoples who are the first? (Demelenne 2011, translated from Spanish)
\end{abstract}

In political speeches, Indigenous Peoples appear to be given priority: 'they will be the first'; yet the day-to-day reality is that they do not see any tangible evidence of this being true. This results not only from a lack of political will, but it is also due to the difficulty of creating new forms of action. Research and diagnosis provide all the necessary data to 'know' the reality of the Indigenous Peoples. These data have been published and disseminated, yet, according to various leaders, it all 'remains on paper'. They claim that, in order to change their reality, it is necessary to go beyond "knowing" and reach 'recognition'. ${ }^{2}$ Knowing is a cognitive exercise achieved from a comprehensive reading of texts. Recognition implies an effort to understand others and their way of being different; it is constructed from interactions. Another Mbyá leader commented on our research work and highlighted the difficulty of constructing a relevant research methodology that can for instance integrate the Guarani concept of temiandu rekavo.

Temiandu means what is felt, and this can not be looked for or researched because it is a feeling. It can be understood as the aim to search for information that truly responds to a need felt by its recipients. In this case, we give it a different meaning (Leader of Pindoyu, Itapua).

In other words, Temiandu rekavo (to find what you feel) cannot be achieved with research tools; it needs a different process. The explanation of the leader reflects the difficulty of achieving in-depth dialogue. It is challenging to understand ways of feeling, living, and thinking that are different from ours. The ways of seeing and behaving are explained using narratives. Ours are meant to be rational and scientific, those of the Indigenous Peoples are based on their own world-views.

In the Mbyá-Guarani culture, the concepts of "ayvu" (human language), "ñe' $\hat{e}$ " (word) and " $e$ " (say) encompass a double meaning: expressing ideas as well as

\footnotetext{
${ }^{2}$ Explanation developed by a Nivacle teacher during a workshop on the definition of Indigenous educational policies.
} 
being a divine portion of the soul (Cadogan 1992). Constructing a deep dialogue implies not only being able to understand the words but also being able to reach the feeling (the divine portion of the soul).

According to Kalisch and Unruh (2018), when we face these different worldviews, we can adopt different attitudes. Some may qualify them as imaginary, not rational but symbolic, or accept that they speak of another reality. For this author, we are facing another type of epistemology. The Indigenous Peoples' way of thinking about the world has the same value as that of academia; it is in-depth knowledge but with a different epistemology.

We can therefore question if it is possible to build a dialogue about feelings between different epistemologies or ways of seeing the world. Indeed, this confrontation with other narratives puts our way of understanding reality in doubt.

The interpreter of the world, the owner of the verb, is suddenly exposed to other interpretations and listening to words that are not an echo or an imitation of his or her verb, which supposedly is the origin of all the names of the world; but, on the contrary, they have their own memory and articulate their own vision of the world (Fornet-Betancourt 2006, p. 30; translated from Spanish).

For Raul Fornet Betancourt, constructing a dialogue under these conditions forces us to redefine its basis. In this regard, it allows us to highlight the ambivalences, ruptures and silences, to focus on their different stories beyond the predominant narrative discourses within each culture (Schramm 2007).

These are the very conditions of interculturality and intercultural education that we must review in order to build a dialogue between different narratives about knowledge and humanity (Fornet-Betancourt 2007). National educational policies initially sought to assimilate different cultures into a single identity, based on a single language, culture and history while intercultural education recognizes diversity and seeks to create a dialogue between different cultures.

There is therefore a need for a more profound approach than the one adopted by the Department of Indigenous Education when it sought to articulate informal Indigenous education and formal schooling. The diversity of narratives forces us to recognize different types of knowledge, including social knowledge produced outside academic institutions, regardless of officially established codes to regulate the production of knowledge (Fornet-Betancourt 2007). As a lot of this knowledge has disappeared through contact with other cultures, Fornet-Betancourt (2007) argues that it is crucial to reconstruct a new equilibrium with other paradigms.

Another aspect to consider in the construction of this dialogue is that we cannot achieve it based on the current paradigms of education that place cultures and people in competition. For Maturana and Dávila (2006), we live and coexist in a culture based on relationships of domination, subjugation and competition, with the consequences of isolation and subsequent pain and suffering for communities and entire ethnic groups throughout the world. Dialogue and listening require an openness to 'know where you do not know' and seize opportunities to learn and not to compete (Maturana and Dávila 2006). 
Furthermore, in today's world, the proposals of interculturality occur in contexts of unequal status, within a perspective of globalization and varied competences. In addition, the increasingly difficult conditions in Indigenous communities force families to migrate to the cities. As a result, traditional political and organizational systems are weakened. Public policies transform leadership and participatory systems, and do not allow effective insertion or participation.

Now the Tamoi cry, because they are destroying their habitat, the land. That is due to lack of respect for Indigenous rights (San Pedro leader, consulted in 2017).

The land, the territory and the environment play a fundamental role in Indigenous communities. They have a spatial, social, political, and spiritual meaning. The land, or rather a 'quality habitat', is the pillar that enables access to other rights, including education, health, and food security. In Indigenous cultures, these concepts cannot be dissociated, and they interact with each another. This 'habitat' has a cultural sense of 'ancestral or traditional territories' which the Mbyá Guarani call tekoha guasu.

In this way, many of the demands and struggles of Indigenous Peoples can be seen as ontological struggles for the defense of other life styles. According to Escobar (2016), these strategies of resistance are shaped by three major concepts: autonomy, commonality, and good living.

As stated above, there is a long history of participation of Indigenous Peoples in the definition of legal frameworks and public policies in Paraguay. The Convention of the Constituent Assembly 1992, was a historic event because Indigenous representatives were included in the Assembly, even if they only had a voice without voting rights. Later, the Second National Indigenous Census of 2002 marked another important milestone that allowed a process of institutionalizing social policies for Indigenous Peoples including the enactment of the Indigenous Education Law, the Indigenous Health Law, the incorporation of Indigenous officials into different public institutions, etc. Despite the political will, we cannot say Indigenous Peoples have achieved effective recognition yet. For a long time, some recognition was given through the concept of citizenship in reference to the construction of a NationState defined as a project of assimilation-integration. However, in the case of the Indigenous Peoples of Paraguay, this integration has not occurred. The absent State not only maintains discrimination but also denies them access to basic rights by keeping them in a situation of extreme poverty and invisibility. This is a consequence of the absence or lack of relevance of public policies and weak participation in the electoral processes and decision-making spaces. Society in general not only ignores their reality and cultures, it denies their existence and discriminates against them.

This is how, our brother said, we have many laws but do not see an effective compliance, either locally or nationally, we are still in a lower stage of development as a people, which is different from others. That is very sad (Indigenous leader San Pedro, consulted in 2017).

Returning to the three concepts above, autonomy is what should allow Indigenous Peoples to be recognized in their capacity to have different and pertinent public 
policies. Communality is the logical framework that recognizes the concept of an Indigenous collective organization, separate from western, social or institutional organizations. Good living is a different project for society, based on a holistic concept inherited from Indigenous worldviews, which presents another way of relating to people, communities, and the universe; and differs from our view of society seeking development and economic growth. It is a project based on a balanced relationship with nature and humanity in which sharing rather than competing is the basis of social interactions. Furthermore, the basis of action must be the social knowledge of communities and 'Indigenous protagonism' as opposed to the knowledge of experts. The construction of Indigenous citizenship should then recognize their autonomy and the possibility of organizing themselves from a community as opposed to an individual right.

As we can see, our CULTURE is ending, we are losing everything. Although there is the Secretariat for Culture, its participation in our communities is not effective, there is no coordinated work to recover or strengthen the culture (...) Many times we find it impossible to strengthen our culture, because today there is the prohibition of entry to sacred sites previously used by our ancestors, to collect traditional remedies, among other things. Then why do we have the law? What is its purpose? (Qom leader San Pedro, consulted in 2017).

For the Indigenous communities of Paraguay, citizenship remains an abstract concept far from their immediate needs. From the perspective of Indigenous citizenship building, it is necessary to transform our views and our interactions.

According to Fernández Droguett (2009), the concept of ethnicity accounts for a relationship between asymmetrical categories resulting from colonialism. The ethnic minorities are constantly redefined, creating a dynamic category, incorporating the political struggle of the Indigenous Peoples to fight from a position of cultural difference. Reina (2000) adds that ethnicity can become a process of searching for a new form of integration, based on the recognition and appreciation of differences, proposing a new form of social organization from cultural pluralism, proceeding towards the formulation of 'ethnic citizenship'.

It is no longer a project to assimilate nor is it an intercultural dialogue. This new form of Indigenous citizenship seeks to promote the protagonism of Indigenous Peoples and, to a certain extent, respect their autonomy. In this way, some authors propose to change the concept of ethnicity and recognize them as nations. Citizenship is constructed from the perspective of pluri-national states as in Ecuador and Bolivia.

The question arises of how to build an Indigenous citizen education from a perspective of pluricultural identity without breaking national citizenship. The search for an answer forces us to review this concept and to base it on effective participation of Indigenous Peoples, recognizing different systems of social organization and leadership. 


\section{An Indigenous Citizenship Education}

Until now, we emphasized understanding citizenship in relation to the living conditions of Indigenous Peoples and stressed the need to redefine this project according to the new challenges. We would like to conclude by explaining the role of education in this project. First of all, it is important to underline that an education project is by its very essence a socialization project and also a commitment towards the construction of a certain type of society. Taking this into consideration citizen education projects, from an Indigenous perspective, should respect and promote the possibility of constructing different ways of defining and articulating social life.

We are here to share our knowledge, to generate our own commitment, they must listen to us so that this can conclude with a result according to what we propose in this meeting (...) Let's talk about participation, this must be our own and not what the state organisms bring us or suggest, we have the capacity to generate our own participation according to our knowledge with the aid of the State (Qom leader San Pedro, consulted in 2017).

Responding to this challenge forces us to review the very roots of our educational projects and, above all, to review our ways of implementing them. In terms of discourse, we can agree with ideas of inclusion, autonomy or protagonism, but how do we solidify them into a national education project that not only respects but also energizes other ways of viewing society, social organizations, and the diversity of knowledge? How can it be done without relinquishing the construction of a society through a common interpretative and normative framework?

When we talk about new methods of implementation, it is important to recognize that, so far, we have neither the know-how to proceed, nor the knowledge of how to train teachers in this direction. We do not know if the educational spaces and the current educational actors are the most relevant for this task. However, it appears certain that a new Indigenous citizenship education needs structural transformation. To search for it is to understand that there is not a single solution, but alternatives that are built in a shared manner. Fornet-Betancourt (2006) points out, it is necessary to start from the existing polyphony and cultural alterity, which means to radically and methodologically widen the sources, to build an educational proposal that truly acknowledges plurality and builds educational actions from different cultural narratives. To recognize that it is not the global forces that should define our field of action, but the stories in which cultures recount their foundations and invite us to discover what defines meaning and disseminates their way of relating to the world (Fornet-Betancourt 2006).

In other words, this type of education cannot be designed, it must be experienced and recreated according to contexts and experiences. Rediscovering GCE from an Indigenous perspective forces us to try to understand the views of Indigenous Peoples towards the world and to accept the coexistence of several perspectives. It means adopting a different way of looking at and living the issues related to rights and citizenship: protagonism, identity and inclusion. 
If we take cultural diversity seriously, we must epistemologically pluralize education so that it is a service in favor of the equilibrium of knowledge. In this way, educational programs would be a space in which dialogue, supported by a great deal of knowledge, takes place and one learns to identify its relative importance in the world we would like to live in (Fornet-Betancourt 2006).

Fornet-Betancourt's (2006) proposal integrates the different dimensions of citizenship education in a holistic perspective where the epicenter of the proposal is displaced. Modern and active education has placed the student at the center of the learning processes in contrast to the Indigenous Peoples of the Ecuadorian Amazon who propose that it should be nature. To leave behind an anthropocentric perspective will force us to conceive of another type of pedagogy, one that would make more sense if we look for an inclusive education, one based on community rights and seeking sustainable development. In order to achieve a more equitable and respectful society of rights, it is necessary to break with methodological individualism and integrate the collective values of justice, equity and solidarity.

Viewed in this way, Indigenous citizenship education is not a goal in itself, but a proposal along with other proposals; it is the link and mediation between different identities. As Indigenous communities are dynamic spaces composed of different cultures (for example, the culture of today's youth is not always in agreement with their parents' culture), the construction of an Indigenous citizenship education is not only the cause of Indigenous Peoples. We must all enter the same dynamic. It supposes the existence of citizenship that surpasses or articulates the identities of the different ethnic or social groups.

\section{Conclusions: Is an Intercultural Citizenship Education Possible?}

Words can only fully be understood in their temporal and special context. For instance, the standard definition of citizenship refers to the possibility of participating in political life within a State governed by a democratic system which implies a capacity for abstraction, while the Indigenous political and participatory system is a more local notion, with specific knowledge and attachment. At these different levels, the words and concepts take on different meanings from the ideas of insertion, roots, autonomy and rights. From the local community perspective, the balance in relationships (with each other or with nature) and the absence of conflicts are important. The word 'tranquility' is frequently used in Paraguay and reflects a sense of 'good living' of the Andean people. It reflects an emotional and spiritual balance.

In this chapter, we can see that educational reforms emphasize inclusion and respect for diversity but are not sufficient to change viewpoints and overcome fears. Ironically, politicians translate their desire to be inclusive by speaking of "our" Indigenous people, but at the same time they deny them space, seize their land and do not even consider them as Paraguayans. 
Access to citizenship for Indigenous Peoples remains a burning issue that is linked to land management. Traditional territory is a vital concept for Indigenous Peoples and it is believed that access to territory is what allows us to be human, while access to rights allows us to be citizens. Furthermore, it must be said that the right to vote in all elections is not sufficient to allow Indigenous Peoples to be part of the public policy agenda as they remain widely unrecognized. Finally, the democratization of formal education has provided increased access to schooling for Indigenous children has yet to meet the challenge of providing equal access to the tools required of actors in a global world.

More than ever, we must be creative to construct educational policies that do not seek to assimilate, but to build dialogue and autonomy in culturally diverse societies. Today, Paraguay is faced with the challenge of constructing a plural education that respects different types of knowledge and being, understood as an experimental proposal capable of reversing views based on the individual and competition, and able to move from "one against the other to one for the other" (Honneth 1997) where the achievement of collective objectives is valued.

For instance, our previous work demonstrated that during a mathematical Olympiad, Indigenous students solved mathematical problems collectively under the leadership of the older students (Demelenne 2014). Of course, this way of working collectively was contrary to the rules of the contest which was based on individual competition. We can learn a lot from the experience of Indigenous teachers who mediate the knowledge of their community, where through intercultural research methodology they seek to rescue community knowledge and share it in academic spaces. But these community experiences are not enough.

The curriculum is the core of our educational policies, it is designed from an equality perspective that seeks to give the same opportunities to all students as equal citizens of the same country. But we are not the same, we are different from a social, economic, and cultural perspective, and also with different epistemological perspectives. An Indigenous citizen education cannot only be achieved through curricular reform, nor can giving the Indigenous Peoples the autonomy to build their own curricula be enough. We need to involve everyone in the possibility of thinking about a different education where we learn to live together "for each other".

\section{References}

Cadogan, L. (1992). Ayvu Rapyta. Textos míticos de los Mbyá-Guaraní del Guairá. Asunción: CEADUC UCA.

Demelenne, D. (2010). El docente investigador como herramienta para la construcción de un nuevo curriculum de educación indígena. Revista Paraguay de Educación, 29-44.

Demelenne, D. (Ed.). (2011). Marco teórico y metodológico del diagnóstico participativo en comunidades indígenas. Asunción: SAS Tapea.

Demelenne, D. (2014). Investigación OMAPA: Inclusión social a través de la Educación: Olimpíadas de Matemática en comunidades indígenas del Paraguay. Asuncion: OMAPA/ CONACYT. 
DGEEC. (2014). Permanent household survey. Main results of poverty and income distribution. Asuncion: DGEEC.

DGEEI. (2013). Sistematización del Proyecto de Educacion Intercultural Bilingüe. Asuncion: MEC. Escobar, A. (2016). Autonomía y diseño: La realización de lo comunal Popayán. Popayán: Universidad del Cauca Sello Editorial.

Fernández Droguett, F. (2009), Etnicidad y ciudadanía indígena: las formas de acción colectiva Aymara en Argentina, Bolivia, Chile y Perú. Si Somos Americanos. Retrieved from: http:// www.redalyc.org/articulo.oa?id=337930336003

Fornet-Betancourt, R. (2006). La interculturalidad a prueba. Aachen: Maniz.

Fornet-Betancourt, R. (2007). "La filosofía intercultural latinoamericana de Raúl FornetBetancourt. Una discusión de sus elementos principales" Christina Schrarnrn in Rev. Filosofía Univ. Costa Rica, XLV (114),77-84, Enero-Abril 2007.

Gómez, S., Moore, C., \& Múnera, L. (Eds.). (2018). Los saberes múltiples y las ciencias sociales y políticas Tomo I. Bogota: Universidad Nacional de Colombia.

Honneth, A. (1997). La lucha por el reconocimiento. Barcelona: Crítica.

Kalisch, H., \& Unruh, E. (2018). No llores! La historia enlhet de la guerra del chaco. Asunción: Servilibro.

Maturana, H., \& Dávila, X. P. (2006). Desde la matriz biológica de la existencia humana. Revista PReLac, 2, 30-39.

Ministry of Agriculture and Livestock, INDI, \& FAO. (2014). National report. Diagnosis and proposals for the development of public policy on food and nutrition security for indigenous peoples in Paraguay. FAO: Santiago.

Reina, L. (Ed.). (2000). Los retos de la etnicidad en los estados-nación del siglo XXI. Ciudad de México: Ciesas/INI/Porrúa.

Schramm, C. (2007). La filosofía intercultural latinoamericana de Raúl Fornet Betancourt. Una discusión de sus elementos principales. Revista de filosofía de la universidad de Costa Rica, XLV(114), 77-84.

Tauli-Corpuz, V. (2015). Informe sobre la situación de los pueblos indígenas en el Paraguay, Naciones Unidas Asamblea General Consejo de Derechos Humanos. Asunción: Paraguay.

Open Access This chapter is distributed under the terms of the Creative Commons Attribution 4.0 International License (http://creativecommons.org/licenses/by/4.0/), which permits use, duplication, adaptation, distribution and reproduction in any medium or format, as long as you give appropriate credit to the original author(s) and the source, a link is provided to the Creative Commons licence and any changes made are indicated.

The images or other third party material in this chapter are included in the work's Creative Commons licence, unless otherwise indicated in the credit line; If such material is not included in the work's Creative Commons licence and the respective action is not permitted by, users will need to obtain permission from the license holder to duplicate, adapt or reproduce the material.

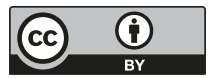

